\title{
Validitas dan Praktikalitas Perangkat Pembelajaran Daring pada Pendidikan Kesetaraan Paket B
}

\author{
Alfitriati ${ }^{1}$, Suci Ramadhani ${ }^{2 *}$ \\ ${ }^{1}$ Universitas Negeri Padang (UNP), Padang, Indonesia \\ ${ }^{2}$ Universitas Andalas (Unand), Padang, Indonesia \\ *Corresponding Author
}

\begin{tabular}{l} 
Informasi Artikel \\
\hline Diterima Redaksi: 10 Juli 2021 \\
Revisi Akhir: 18 November 2021 \\
Diterbitkan Online: 31 Desember 2021 \\
Kata Kunci \\
\hline Validitas, Praktikalitas, RME \\
Korespondensi \\
\hline Email: sucisuryabayu3012@gmail.com
\end{tabular}

\author{
A B S T R A C T
}

\begin{abstract}
This study aims to determine the validity and practicality of the product developed in the form of a mathematics learning device based on Realistic Mathematical Education (RME) in the flat-sided geometry material for Package B students equivalent to class VIII SMP. This research was conducted at the Kasih Bundo Community Learning Activity Center, Bukittinggi. This research is a development research using the Plomp development model. The results of the research discussed are related to the results of the validity test and practicality test. The validity test is based on the results of the expert review, while the practicality is based on one to one and small group trials in the field. The validity test obtained very valid criteria, while for the one to one and small group activities it was found that there was an increase after using the student worksheet (LKPD) which was developed using the RME approach.
\end{abstract}

Penelitian ini bertujuan untuk mengetahui validitas dan praktikalitas dari produk yang dikembangkan berupa perangkat pem,belajaran matematika berbasis Realistic Mathematic Education (RME) pada materi bangun ruang sisi datar untuk siswa Paket B setara kelas VIII SMP. Penelitian ini dilakukukan di Pusat Kegiatan Belajar Masyarakat Kasih Bundo Bukittinggi. Penelitian merupakan penelitian pengembangan menggunakan model pengembangan Plomp. Hasil penelitian yang dibahas terkait hasil uji validitas dan uji praktikalitas. Uji validitas berdasarkan hasil expert review sedangkan praktikalitas berdasarkan uji coba one to one dan small group di lapangan. Uji validitas tersebut memperoleh kriteria sangat valid, sedangkan untuk kegiatan one to one dan small group diketahui adanya peningkatan setelah menggunakan lembar kerja peserta didik (LKPD) yang dikembangkan menggunakan pendekatan RME.

02021 by the authors. Submitted for possible open access publication under the terms and conditions of the Creative Commons Attribution-ShareAlike 4.0 International License-(CC-BY-SA) (https://creativecommons.org/licenses/by-sa/4.0/)

\section{Pendahuluan}

Pendidikan di Indonesia menurut Undan-undang nomor 20 tahun 2003 terdiri atas pendidikan formal, pendidikan nonformal, dan pendidikan informal. Pendidikan nonformal dan informal merupakan alternatif pendidikan yang bisa dilalui oleh setiap rakyat Indonesia dengan ketentuan sesuai aturan yang ada. Kegiatan pendidikan dapat diaktualisasikan dalam pembelajaran. Kota Bukittinggi memiliki beberapa lembaga penyelenggara pendidikan non formal baik dikelola pemerintah maupun masyarakat. Lembaga yang dikelola oleh masyarakat disebut Pusat Kegitan Belajar Masyarakat (PKBM) yang salah satunya adalah PKBM Kasih Bundo yang menyelenggarakan pendidikan kesetaraan diantaranya Program Paket B setara kelas VIII SMP.

Pembelajaran yang dilakukan pada pendidikan kesetaraan bukan hanya berorientasi untuk memperoleh ijazah atau bukan sekedar transfer pengetahuan (transfer of knowledge), tetapi juga merupakan transfer belajar (transfer of learning) yang harus menghasilkan transformasi pola pikir dan pola tindak [2]. Usaha membelajarkan peserta didik dimaksudkan 
agar peserta didik yang pada umumnya adalah usia sekolah dapat berpeluang kembali mengakses pendidikan formal pada jenjang pendidikan yang lebih tinggi.

Berbagai upaya dilakukan lembaga untuk hal tersebut, namun masih dalam upaya memperlancar pertemuan secara langsung. Salah satunya dengan melakukan pemetaan dengan perancangan perangkat pembelajaran paket B, pada saat implementasi KTSP pada PKBM Kasih Bundo namun belum maksimal [1], dilanjutkan dengan pemetaan Satuan Kredit Kompetensi (SKK) dan juga perangkat pembelajaran belum dapat dirancang dengan baik sesuai cara pembelajaran yang tepat dengan analisis konteks [1]. Selain itu, permasalahan yang dominan terjadi pada pendidikan kesetaraan adalah motivasi belajar yang kurang yang ditunjukkan dari kehadiran peserta didik dalam setiap pertemuan dan apabila mereka lelah maka akan ada peserta didik yang pulang duluan sebelum jadwal. Masalah tersebut juga menyebabkan tidak dapat terukurnya keefektifan perangkat pembelajaran yang telah dirancang sebelumnya dengan baik.

Kondisi saat ini menyebabkan pembelajaran matematika dilaksanakan sesuai SE Mendikbud mengenai Pembelajaran secara daring. Pembelajaran pada masa pandemic Covid-19 juga menuntut pendidik mampu melaksanakan pembelajaran daring yang menyenangkan Pembelajaran daring memiliki kekuatan, tantangan dan hambatan tersendiri (Sadikin, Hamidah,2020). Temuan lapangan menyatakan bahwa pendidik matematika tidak melakukan ujian berupa ulangan harian, hanya melakukan Ujian akhir semester saja menggunakan aplikasi Quizziz berbatas waktu dan hasilnya pun kurang memuaskan karena ternyata lebih banyak peserta didik yang memperoleh nilai di bawah KKM (khusus di awal daring pada masa pandemic). Ketuntasan hasil belajar siswa dapat dilihat melalui tabel 1 berikut.

Tabel 1. Ketuntasan Hasil Belajar Matematika Peserta didik Berdasarkan Hasil Ulangan Harian Semester 1

\begin{tabular}{|c|c|c|c|}
\hline Kelas & Waktu & Tuntas & Tidak Tuntas \\
\hline Tingkat Terampil I & Sebelum Pandemi (setara kelas VII) & $45 \%$ & $55 \%$ \\
\hline setara Kelas VIII SMP & Saat Pandemi & $30 \%$ & $70 \%$ \\
\hline
\end{tabular}

Pembelajaran berbasis daring adalah pembelajaran yang diselenggarakan melalui jejaring web. Setiap mata pelajaran menyediakan materi dalam bentuk rekaman video atau slideshow, dengan tugas-tugas mingguan yang harus dikerjakan dengan batas waktu pengerjaan yang telah ditentukan dan beragam sistem penilaian. Pembelajaran daring membutuhkan tanggungjawab, kemandirian dan ketekunan pribadi, karena tidak ada yang mengontrol selain dirinya sendiri. Mereka harus mendownload dan membaca materi, menjawab quiz/soal serta mensubmit tugas secara mandiri. Selain itu pembelajaran daring memerlukan media pembelajaran yang variatif seperti media video pembelajaran yang terhubung ke youtube, media video conference, media jurnal ilmiah atau topik yang tersistem secara digital.

Hal ini sejalan dengan tuntutan kurikulum pendidikan Indonesia yakni membuat pembelajaran yang aktif, kreatif, inovatif, menyenangkan, menantang, dan memotivasi peserta didik untuk berpartisipasi aktif dalam proses pembelajaran. Penggunaan teknologi seperti komputer, multimedia interaktif, software-software matematika, perangkat mobile berbasis Android dapat meningkatkan pemahaman peserta didik tentang materi matematika, [5] menunjukkan bahwa penggunaan multimedia interaktif dan software-software matematika mampu meningkatkan motivasi dan pemahaman peserta didik. Teknologi dapat membantu peserta didik dalam mensimulasikan, memodelkan, membuat percobaan, dan melihat visualisasi atau demonstrasi untuk memperjelas suatu konsep. Retensi peserta didik terkait materi tertentu meningkat berkat penggunaan teknologi dalam pembelajaran. Hal ini sejalan dengan Coneof 
Learning yang disampaikan Edgar Dale bahwa simbol dan gagasan yang abstrak dapat lebih mudah dipahami dan diserap manakala diberikan dalam bentuk pengalaman yang konkrit [11].

Berdasarkan deskripsi di atas, rumusan masalah dalam penelitian ini adalah bagaimana karakteristik desain pembelajaran matematika berbasis daring pendidikan kesetaraan paket B yang memenuhi kriteria valid dan praktis. Produk yang dihasilkan adalah alur belajar berbasis RME dengan produk awal berupa Rencana Pelaksanaan Pembelajaran (RPP) yang dilengkapi Hypothetical Learning Trajectory (HLT). Produk juga dilengkapi dengan Lembar Kerja Peserta Didik (LKPD) dengan berbasis Realistic Mathematics Educaition (RME).

\section{Metode Penelitian}

Penelitian ini merupakan penelitian pengembangan atau Research and Development $(R \& D)$. Model pengembangan merupakan rangkaian prosedur yang berurutan dalam melaksanakan pengembangan dan perancangan pembelajaran yang direpresentasikan dalam bentuk diagram dan naratif. Model pengembangan yang diterapkan dalam penelitian ini adalah model pengembangan yang dikembangkan oleh Tjeerd Plomp. Dalam model pengembangan tersebut, apapun tujuan penelitian pengembangan, proses pengembangan harus menggabungkan proses desain pendidikan yang sistematis. Secara umum model Plomp dapat dilihat pada Gambar 1 berikut:

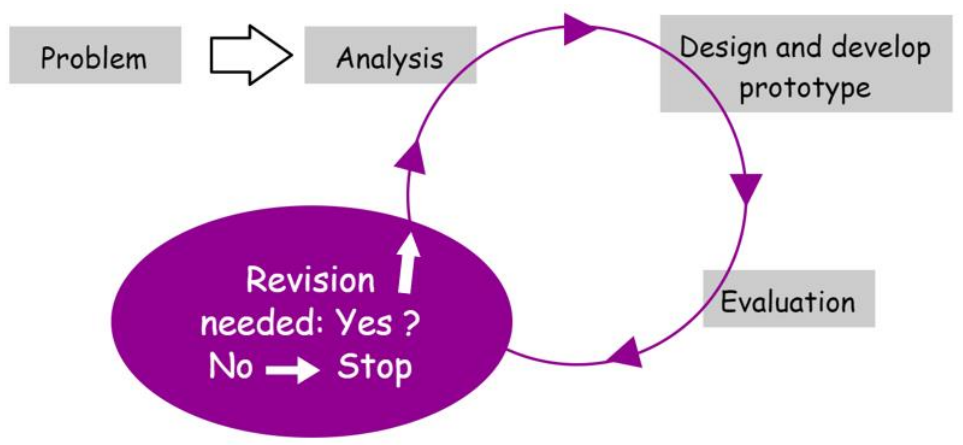

Gambar 1. Iterasi Siklus Desain Pengembangan yang Sistematis [6]

Menurut [6], apapun tujuan penilitian pengembangan, proses penelitian selalu menggabungkan dengan proses desain pendidikan secara sistematis seperti pada Gambar 1 . Berdasarkan perulangan siklus pengembangan Plomp, terdapat tiga fase pengembangan, yaitu analisis pendahulan (preliminary research), fase design dan develop (development or prototyping phase), dan fase penilaian (assessment phase).

Model pengembangan yang dipakai pada penelitian ini adalah model pengembangan plomp. Prosedur pengembangan pada penilitian ini dibagi menjadi tiga fase yang secara umum dapat dilihat pada table 2 berikut ini:

Tabel 1. Tahap Pengembangan Produk

\begin{tabular}{lll}
\hline \multicolumn{1}{c}{ Tahap } & \multicolumn{1}{c}{ Kriteria } & \multicolumn{1}{c}{ Deskripsi Aktivitas } \\
\hline Preliminary & Lebih menekankan pada & Analisis masalah dan studi literatur. \\
research & validasi, tidak banyak untuk & Hasil dari tahap ini adalah bentuk \\
& konsistensi dan kepraktisan. & rancangan awal prototype. \\
Prototyping & Fokus pada: konsistensi & Pengembangan prototype yang akan \\
stage & (validasi konstruk) dan & diujicobakan dan direvisi berdasarkan \\
\hline
\end{tabular}




\begin{tabular}{lll}
\hline Assessment & praktikalitas produk & evaluasi formatif. \\
phase & efisiensi/ efektivitas produk & $\begin{array}{l}\text { Menilai apakah produk tersebut } \\
\text { efektif }\end{array}$ \\
\hline & Sumber: Terjemahan dan modifikasi Plomp (2013:30)
\end{tabular}

Pada tahap pengembangan akan dihasilkan perangkat pembelajaran berupa Rancangan Pelaksanaan Pembelajaran (RPP) dan LKPD. Tahapan ini terdiri dari (a) Validasi perangkat pembelajaran. Perangkat pembelajaran yang dirancang pendidik dan akan digunakan peserta didik terlebih dahulu divalidasi.Validasi ini meliputi kelayakan isi, kontruksi dan bahasa.Pengujian validitas produk dilakukan dengan melakukan lembaran validitas yang disusun dan divalidasi terlebih dahulu. (b) Tahap revisi. Tahap revisi dilalui apabila hasil penilaian validator ditemukan beberapa bagian pada RPP daring yang perlu diperbaiki. Perangkat pembelajaran yang telah direvisi, diberikan kembali ke validator untuk didiskusikan lebih lanjut. Revisi dihentikan apabila validator sudah menyatakan perangkat pembelajaran yang sudah dibuat dapat diujicobakan. (c) Tahap uji coba. Produk yang dihasilkan diujicobakan pada peserta didik semester II program paket B setara kelas VIII SMP/MTs. Adapun aspek yang diamati adalah keterlaksanaan perangkat pembelajaran. Pada tahap ini dilaksanakan uji coba untuk melihat validitas dan praktikalitas desain pembelajaran dengan memberikan produk penelitian kepada peserta didik dan meminta respon dari pendidik dan peserta didik melalui wawancara.

\section{Hasil dan Pembahasan}

\subsection{Hasil Evaluasi Sendiri (Self Evaluation)}

Hasil rancangan awal perangkat pembelajaran disebut prototype 1. Setelah perangkat pembelajaran di rancang maka dilakukan evaluasi sendiri sebelum divalidasi oleh para ahli. Evaluasi sendiri dilakukan dengan cara melihat kesalahan-kesalahan yang terdapat pada perangkat pembelajaran yang telah dirancang. Aspek yang di evaluasi pada RPP dan LKPD adalah aspek isi, bahasa, dan penyajian seperti ketepatan pengetikkan, bahasa yang kurang efektif, kelengkapan komponen RPP dan LKPD, ketepatan tanda baca, penggunaan kata, kesesuaian kegiatan pembelajaran dengan karakteristik RME, ketepatan dalam penggunaan gambar, ketersediaan tempat untuk menyelesaikan masalah, ketepatan ukuran tulisan.

Secara umum, kesalahan banyak terjadi pada pengetikkan dan tanda baca. Kesalahan pengetikkan seperti kata "peserta didik" tertulis "peserta didik", kata "bersama-sama" tertulis "bersama-sama kata "di atas" tertulis "diatas". Kemudian terdapat kata yang tertulis tidak lengkap seperti kata "pembelajaran" tetulis "pembeljran" dan "volume" tertulis "olume". Kelupaan penggunaan spasi antar dua kalimat seperti "di atas" yang tertulis "diatas".

\subsection{Hasil Validasi Desain Pembelajaran Oleh Para Pakar (Expert Reviews)}

Perangkat pembelajaran yang telah direvisi sesuai dengan hasil evaluasi yang ada pada lembar self evaluation selanjutnya akan di validasi dan didiskusikan oleh pakar. Desain pembelajaran tersebut di validasi oleh 5 orang pakar yang terdiri dari 3 orang pakar pendidikan matematika, 1 orang pakar teknologi pendidikan, dan 1 orang pakar bahasa Indonesia. Nama validator tersebut dapat dilihat pada lampiran 1.

Hasil validasi terhadap desain dilakukan oleh 5 orang pakar. Aspek yang dinilai dari desain antara lain adalah komponen dan format RPP, identitas RPP, indikator pencapaian kompetensi, tujuan pembelajaran, materi ajar, model pembelajaran, langkah-langkah 
pembelajaran yang sesuai dengan RME, sumber dan media pembelajaran, penilaian, dan bahasa dan penulisan. Saran-saran dari validator untuk perbaikkan RPP dapat dilihat pada tabel 3.

Tabel 3. Saran Validator dan Revisi RPP

\begin{tabular}{|c|c|c|c|}
\hline Validator & Saran & Sebelum Revisi & Setelah Revisi \\
\hline 1 & - & - & - \\
\hline 2 & - & - & - \\
\hline 3 & - & - & - \\
\hline \multirow[t]{2}{*}{4} & $\begin{array}{l}\text { Sebaiknya RPP sesuai K } 13 \\
\text { dan Pembelajaran abad } 21 \\
\text { Lengkapi kegiatan } \\
\text { pembelajaran berbasis online }\end{array}$ & $\begin{array}{l}\text { Terdapat contoh masalah } \\
\text { dan jawaban di HLT } \\
\text { Belum ada dibuat media } \\
\text { daring yang akan } \\
\text { digunakan }\end{array}$ & $\begin{array}{l}\text { Ditambahkan } \\
\text { alternati jawaban } \\
\text { Sudah ditambahkan } \\
\text { media daring yang } \\
\text { digunakan }\end{array}$ \\
\hline & $\begin{array}{l}\text { Cantumkan referensi yang } \\
\text { digunakan pada RPP }\end{array}$ & Belum dicantumkan & $\begin{array}{l}\text { Sudah dicantumkan } \\
\text { referensi }\end{array}$ \\
\hline 5 & $\begin{array}{l}\text { Perbaiki bahasa agar lebih } \\
\text { efektif }\end{array}$ & $\begin{array}{l}\text { Bahasa kurang tepat dan } \\
\text { perlu lebih teliti dalam } \\
\text { penulisan }\end{array}$ & $\begin{array}{l}\text { Bahasa } \\
\text { disempurnakan agar } \\
\text { lebih komunikatif }\end{array}$ \\
\hline
\end{tabular}

Keterangan:

Validator 1, 2 dan 3 : Pakar Pendidikan Matematika

Validator 4 : Pakar Teknologi Pendidikan

Validator $5 \quad$ : Pakar Bahasa

Setelah perbaikkan dilakukan, kemudian validator memberikan penilaian terhadap RPP yang dirancang. Analisis hasil validasi validator dapat dilihat pada 4 berikut.

Tabel 4. Hasil Validasi RPP Secara Keseluruhan

\begin{tabular}{llcl}
\hline No & \multicolumn{1}{c}{ Aspek yang Dinilai } & $\begin{array}{c}\text { Nilai } \\
\text { Validitas }\end{array}$ & Kategori \\
\hline $\mathbf{1}$ & Identitas Mata Pelajaran & $90 \%$ & Sangat Valid \\
$\mathbf{2}$ & Kompetensi Dasar (KD) & $90 \%$ & Sangat Valid \\
$\mathbf{3}$ & Perumusan Indikator Pembelajaran & $87,5 \%$ & Sangat Valid \\
$\mathbf{4}$ & Perumusan Tujuan Pembelajaran & $87,5 \%$ & Sangat Valid \\
$\mathbf{5}$ & Pemilihan Materi Pembelajaran & $88 \%$ & Sangat Valid \\
$\mathbf{6}$ & Pemilihan strategi Pembelajaran & $83,3 \%$ & Sangat Valid \\
$\mathbf{7}$ & Pemilihan Sumber Belajar & $83,3 \%$ & Sangat Valid \\
$\mathbf{8}$ & Pemilihan Media Pembelajaran & $80 \%$ & Sangat Valid \\
$\mathbf{9}$ & Langkah-langkah Kegiatan & $85 \%$ & Sangat Valid \\
& Pembelajaran & & \\
$\mathbf{1 0}$ & Penilaian & $92,5 \%$ & Sangat Valid \\
$\mathbf{1 1}$ & Bahasa dan Penulisan & $92,5 \%$ & Sangat Valid \\
\hline
\end{tabular}

Berdasarkan tabel 4 dapat disimpulkan bahwa rata-rata kevalidan seluruh aspek yang dinilai adalah 87,24 \% dan termasuk kategori sangat valid. Artinya RPP berbasis RME ini sudah valid.

\subsection{Hasil Evaluasi Satu-satu (One to One Evaluation)}

Hasil perbaikkan prototype 1 yaitu prototype 2 pada LKPD dilakukan evaluasi satu-satu. Evaluasi satu-satu dilakukan kepada 3 orang peserta didik dari Paket B setara kelas VIII. Ketiga peserta didik tersebut memiliki kemampuan akademik yang berbeda, 1 orang kemampuan tinggi, 1 orang kemampuan sedang, dan 1 orang kemampuan rendah. Peserta didik diminta untuk membaca, mengomentari dan mengerjakan LKPD. Pada saat peserta didik mengerjakan LKPD peneliti melakukan observasi terhadap kegiatan peserta didik tersebut. 
Setelah peserta didik selesai mengerjakan LKPD, peneliti melakukan wawancara untuk mengetahui respon peserta didik mengenai LKPD yang telah dikerjakan. Evaluasi ini dilakukan terhadap 5 LKPD yang dilakukan dalam 2 kali kegiatan dengan uraian sebagai berikut:

\subsubsection{Kegiatan Pertama}

Kegiatan evaluasi satu-satu pada pertemuan pertama dilakukan pada tanggal 14 Maret 2021. Pokok bahasan pada pertemuan 1 adalah "Konsep bangun ruang sisi datar". Pada kegiatan ini ketiga peserta didik diminta untuk memperhatikan kejelasan petunjuk LKPD, kesalahan pengetikkan yang terdapat pada LKPD, dan melakukan aktivitas yang terdapat pada LKPD tersebut.

Berdasarkan observasi terlihat peserta didik sedikit sulit memahami permasalahan yang disajikan, kemudian salah seorang peserta didik bertanya untuk meyakinkan pemahamannya terhadap permasahan tersebut. Peserta didik juga menemukan beberapa kesalahan dalam pengetikkan. Saat peserta didik mencoba menjawab pertanyaan-pertanyaan yang disajikan, peserta didik kelihatan kebingungan memahami pertanyaan-pertanyaan yang disajikan sehingga peserta didik membutuhkan bantuan atau arahan untuk menjawab pertanyaan tersebut. Karena belum terbiasanya pendidik menggunakan pembelajaran ini, maka di awal pembelajaran pendidik melakukan seperti tanya jawab biasa dan kurang menekankan pada karakteristik RME serta pedoman HLT yang ada. Pendidik belum memahami secara baik alur belajar yang digunakan. Penggunaan konteks pembelajaran belum dilaksanakan sebagai acuan untuk memulai masalah dari konteks nyata. Pendidik belum menggunakan benda-benda yang berada disekitar peserta didik untuk membangun pengetahuan peserta didik.

Pendidik menjelaskan materi dasar tatap muka ternyata masuk atau mengimplementasikan indicator pada tutorial juga, namun belum kontekstual. Setelah diingatkan peneliti baru pendidik memanfaatkan benda disekitar peserta didik. Namun terkendala pada benda yang berbentuk balok saja tidak ada benda disekitar peserta didik yang berbentuk kubus, namun pendidik berupaya mengarahkan agar peserta didik dapat menemukan benda kongkrit yang ada. Pendidik meminta peserta didik mengidentifikasi benda yang sudah dimiliki, dengan menunjukkan bagian dari kotak dengan pembimbingan. Pada saat pembelajaran berlangsung pendidik kurang berpedoman pada alternative jawaban dan antisipasi yang diberikan, sehingga diingatkan lagi oleh peneliti.

Pada saat pembimbingan pendidik muncul pertanyaan symbol matematika apa yang digunakan untuk menunjukkan rusuk yang ada pada bangun ruang. Misalnya pada kubus disebut rusuk sehingga disimbolkan $r$, pada balok ada panjang, lebar, tinggi yang disimbolkan dengan $\mathrm{p}, \mathrm{l}$, dan $\mathrm{t}$. Peserta didik kesulitan menentukan istilah sisi pada bangun ruang, namun diarahkan terus oleh pendidik sehingga akhirnya peserta didik dapat menjawab. Perlu ditambahkan jumlah sisi yang kongruen pada bangun datar dan letaknya. Pendidik telah mengarahkan peserta didik menjawab pertanyaan yang ada di LKPD dengan menshare screen. Namun sebelumnya peserta didik sudah dibekali dengan hardcopy dari LKPD tersebut 1 hari sebelumnya. Pendidik memberikan waktu pengerjaan LKPD dan meminta peserta didik menunjukkan secara virtual hasil kerjanya.

Sebelumnya, pendidik telah masuk ketutorial tentang luas bangun ruang kubus dan balok. Namun belum mengarah pada tujuan model of dari benda kongkrit. Sehingga nanti ketemu yang namanya jarring-jaring kubus dan balok. Dari jarring-jaring pendidik meminta peserta didik membuat jaring-jaring minimal 2 agar terlihat bentuk bangun datar penyusunnya. Peserta didik menunjukkan hasil yang mereka buat, namun pendidik meminta pembuktian salah satunya menyuruh peserta didik menggunting hasil tersebut agar bisa ditentukan benar atau tidaknya 
Kelemahan yang dilihat diaplikatifnya pendidik masih kurang membangun pengetahuan peserta didik dari konteks nyata, model of, model for, dan bentuk formal. Pendidik cendrung konteks nyata langsung ke formal tanpa bimbingan. Terutama dalam tatap muka. Sedangkan dengan pendampingan peneliti, hal tersebut dapat dibenahi meskipun pembelajaran terkesan maju mundur dan mengulang penyampaian. Saran pendidik pada jarring-jaring untuk lebih paham peserta didiknya, diminta untuk menuliskan mana yang panjang, lebar, tinggi sehingga rusuknya dapat diketahui peserta didik dengan jelas.

Untuk masalah 3 peserta didik menyatakan di awal tidak paham dengan apa yang dimaksud masalah tersebut. Maka pendidik membimbing peserta didik dan membangun pemahaman menganai memahami masalah. Pendidik menanyakan berapa panjang, lebar dan tinggi dari soal dan peserta didik dapat menentukan dengan baik. Pada LKPD tutorial 3 ada yang diganti soalnya yaitu kotak mainan dijadikan ruangan. Pada akhir pembelajaran peserta didik diminta untuk menyimpulkan secara individu apa yang sudah mereka pahami. Dari jawaban peserta didik pendidik memberikan pertanyaan tambahan untuk melakukan pendalaman lebih jauh. Pendidik juga menanyakan bagian lain yang belum disimpulkan peserta didik dan ternyata peserta didik dapat menjawab dengan benar. Pembelajaran dilanjutkan di wag karena pendidik sudah membuat grup khusus dengan peserta didik. Terkait kesulitan pengerjaan LKPD.

Selain itu, juga terdapat tempat penulisan jawaban yang kurang memadai sehingga peserta didik kekurangan tempat untuk menuliskan jawaban. Namun, dilihat dari pemahaman peserta didik terhadap petunjuk LKPD, peserta didik dapat memahami petunjuk yang ada pada LKPD tersebut. Berdasarkan hasil observasi dan wawancara tersebut dilakukan beberapa revisi terhadap LKPD tatap muka dan tutorial 1. Nilai yang diperoleh peserta didik dalam menyelesaikan soal yang berkaitan dengan kemampuan pemecahan masalah adalah sebagai berikut.

\subsubsection{Kegiatan 2}

Kegiatan evaluasi satu-satu pada pertemuan kedua dilakukan pada tanggal 14 Maret 2021. Pokok bahasan pada pertemuan 2 adalah "Menyelesaiakan permasalahan terkait luas dan volume kubus dan balok" Pada kegiatan ini peserta didik juga diminta untuk memperhatikan kejelasan petunjuk LKPD, kesalahan pengetikkan yang terdapat pada LKPD, dan mengerjakan pertanyaan-pertanyaan yang terdapat pada LKPD tersebut.

Kegiatan awal yang dilakukan adalah mereview materi sebelumnya tentang luas permukaan kubus dan balok. Pendidik menyebut subsitusi dengan memasukkan dan pendidik memberikan arahan untuk pembenaran yaitu mengganti. Pendidik sudah mulai memperhatikan tahapan HLT dan mengarahkan peserta didik menemukan konsep sendiri. Namun tidak ada media yang digunakan secara kongkrit menuju ke abstrak, karena peserta didik belum mempersiapkan media tersebut sesuai arahan pendidik pada pertemuan sebelumnya. Pendidik juga tidak menyiapkan media, karena berasumsi bahwa peserta didik sudah mempersiapkan media tersebut. Jadi untuk tahapan berikutny, pendidik perlu dipersiapkan media pembelajaran yang dibutuhkan sesuai materi yang akan disampaikan..

Bagaimana cara ananda menentukan isi, peserta didik menjawab dengan volume dan menyebutkan rumusnya. Meskipun bisa tapi peserta didik salah menjawab hasil akhir dan pendidik mengarahkan dan akhirnya peserta didik mampu menjawab. Pada saat peserta didik ditanya kegunaan volume dalam kehidupan sehari-hari peserta didik menjawab isi air di ember. Lalu pendidik meminta peserta didik menyebutkan bentuk ember. Sehingga mereka menyebut bak air. Selain itu peserta didik lain menyebut masukkan kue dalam kotak. Sedangkan peserta 
didik terakhir menyebutkan mengisi adonan kue ke loyang. Sehingga gunanya dalam hidup dapat mengetahui isi atau kapasitas suatu benda.

Berdasarkan observasi diperoleh informasi bahwa peserta didik sudah mulai memahami pertanyaan yang disajikan meskipun terkadang peserta didik sedikit kesulitan menuliskan jawaban. Nilai yang diperoleh peserta didik dalam menyelesaikan soal yang berkaitan dengan kemampuan pemecahan masalah pada tahap one to one adalah sebagai berikut.

Tabel 5. Persentase Nilai Kemampuan Pemecahan Masalah Tahap One to One

\begin{tabular}{|c|c|c|c|c|c|c|c|c|c|c|c|c|c|}
\hline \multirow{3}{*}{$\begin{array}{c}\text { No } \\
1 \\
\end{array}$} & \multirow[t]{2}{*}{ Indikator Pemecahan Masalah } & \multicolumn{12}{|c|}{ Skor } \\
\hline & & \multicolumn{4}{|c|}{ PD1 } & \multicolumn{4}{|c|}{ PD2 } & \multicolumn{4}{|c|}{ PD3 } \\
\hline & Memahami Masalah & 2 & 2 & 2 & 1 & 2 & 2 & 1 & 2 & 1 & 1 & 2 & 1 \\
\hline 2 & Merencanakan Penyelesaian & 2 & 2 & 2 & 2 & 2 & 2 & 3 & 2 & 2 & 1 & 2 & 2 \\
\hline 3 & Menyelesaikan Masalah & 2 & 3 & 3 & 3 & 2 & 2 & 2 & 1 & 2 & 2 & 2 & 1 \\
\hline 4 & Memeriksa Kembali & 1 & 1 & 1 & 2 & 1 & 1 & 1 & 1 & 1 & 1 & 1 & 1 \\
\hline & Total & 7 & 8 & 8 & 8 & 7 & 7 & 7 & 6 & 6 & 5 & 7 & 5 \\
\hline & Persentase & \multicolumn{4}{|c|}{$70,45 \%$} & \multicolumn{4}{|c|}{$61,36 \%$} & \multicolumn{4}{|c|}{$52,27 \%$} \\
\hline
\end{tabular}

Ket : PD 1= Kemampuan Tinggi

PD 2 = Kemampuan sedang

PD 3 = Kemampuan Rendah

Berdasarkan Tabel 4 terlihat bahwa kemampuan peserta didik dalam indikator memahami Masalah sudah baik ini terlihat dari data bahwa rata-rata peserta didik dengan kemampuan tinggi sedang dan rendah mendapat poin 2 hanya peserta didik dengan kemampuan tinggi pada soal kegiatan empat mendapat poin 1 . Indikator merencanakan penyelesaian rata-rata kemampuan peserta didik sudah baik ini terlihat dari peserta didik dengan kemampuan tinggi mendapat nilai maksimal yaitu 3 sedangkan peserta didik dengan kemampuan sedang dan rendah masing-masing mendapat poin 2 dan 3.

Indikator menyelesaikan masalah peserta didik dengan kemampuan tinggi bisa mengerjakan dengan baik dan mendapat hasil yang benar. Peserta didik dengan kemampuan sedang mendapat poin 2 dimana pada jawaban peserta didik terdapat kesalahan pada hasil akhir hitungan sedangkan peserta didik dengan kemampuan rendah mendapat poin 2 dan 1 untuk masing-masing soal karena pada jawaban peserta didik terdapat langkah penyelesaian yang kurang dan jawaban juga salah. Pada bagian indikator memeriksa kembali peserta didik ratarata mendapat poin 1 .

\subsection{Hasil Evaluasi Kelompok Kecil (Small Group Evaluation)}

Setelah dilakukan kegiatan evaluasi satu-satu maka dilakukan perbaikan terhadap LKPD. Hasil perbaikkan tesebut dinamakan prototype 3. Pada prototype 3 dilakukan kegiatan evaluasi kelompok kecil (small group evaluation). Evaluasi kelompok kecil ini dilakukan terhadap 6 orang peserta didik dari Paket B setara kelas 8 SMP dengan kemampuan akademik yang berbeda. Pada kegiatan ini peserta didik di bagi menjadi 2 kelompok dimana 1 kelompok terdiri dari 3 orang peserta didik yang terdiri dari 1 orang berkemampuan tinggi, 1 orang berkemampuan sedang, dan 1 orang berkemampuan rendah. Berikut ini uraian kegiatan pada evaluasi kelompok kecil:

\subsubsection{Kegiatan 1}

Kegiatan pada pertemuan 1 dilakukan pada tanggal 4 Mei 2021. Materi yang di bahas pada pertemuan pertama adalah "Konsep Bangun Ruang". Pada kegiatan ini pendidik mengajar sesuai dengan proses pembelajaran yang dirancang dalam RPP. Pembelajaran diawali dengan 
pendidik menyapa peserta didik dan berdoa bersama. Kemudian pendidik menanyakan kabar peserta didik. Peserta merespon pendidik dengan baik secara virtual melalui media zoom.

Selanjutnya, pendidik menyampaikan topik dan tujuan materi yang akan dipelajari serta memotivasi peserta didik. Saat pendidik menjelaskan model pembelajaran yang akan digunakan, peserta didik kelihatan bingung. Kemudian pendidik meyakinkan peserta didik dan memberikan LKPD. Saat pendidik meminta peserta didik memahami permasalahan yang disajikan dalam LKPD, peserta didik kelihatan bingung memikirkan maksud dari soal tersebut dan langkahlangkah apa yang akan digunakan untuk menyelesaikan permasalahan tersebut dengan baik. Kemudian, pendidik membagi peserta didik menjadi dua kelompok dan meminta peserta didik mendiskusikan penyelesaian dari masalah-masalah yang terdapat pada LKPD tersebut. Peserta didik dalam kelompoknya kelihatan bingung menyelesaiakan permasalahan tersebut. Pendidik memberikan arahan secara individu maupun kelompok dalam menyelesaikan permasalahan tersebut.

Peserta didik juga kelihatan belum paham dengan pertanyaan-pertanyaan yang terdapat pada LKPD tersebut. Pendidik secara perlahan dan berkali-kali mengarahkan. Namun, hanya beberapa pertanyaan yang dapat di jawab dengan benar. Setelah peserta didik selesai melakukan aktivitas, pendidik meminta salah satu peserta didik untuk mempresentasikan hasil yang diperoleh dengan memperlihatkan melalui layar virtual, namun peserta didik terlihat takut dan tidak percaya diri. Hal ini karena sebelumnya peserta didik tidak terbiasa untuk persentasi di depan kelas. Peserta didik yang mempresentasikan hasil yang diperoleh dengan kelihatan malu-malu. Saat peserta didik diminta menanggapi temannya yang persentasi juga tidak ada. Pada pertemuan ini, persentasi terbatas waktu karena waktu banyak digunakan saat diskusi. Gambar kegiatan dapat dilihat tampilan berikut:

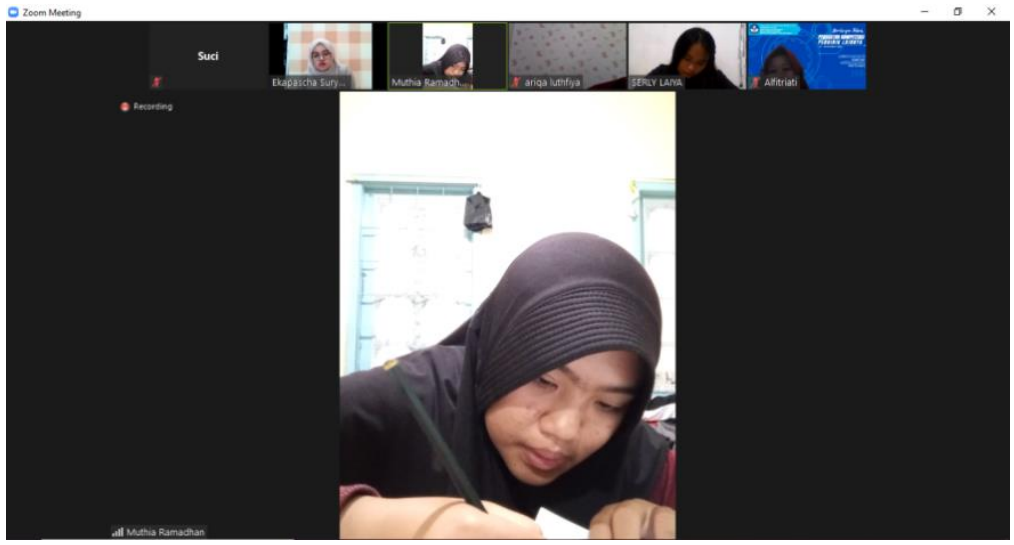

Gambar 2. Kegiatan Small Group

\subsubsection{Kegiatan 2}

Kegiatan pada pertemuan 2 dilakukan pada tanggal 6 Mei 2021. Materi yang di bahas pada pertemuan ini adalah "Menyelesaikan permasalahan terkait luas dan volume kubus dan balok". Pada kegiatan inti peserta didik juga diminta untuk menyelesaikan masalah-masalah pada LKPD yang diberikan dengan menjawab pertanyaan-pertanyaan yang ada. Saat peserta didik menjawab pertanyaan-pertanyaan pada LKPD, peserta didik masih kelihatan bingung terutama pada pertanyaan pada kegiatan tutorial 2 dan 3. Pendidik memberikan arahan kepada peserta didik agar peserta didik dapat menyelesaikan permasalahn tersebut dengan baik. Dalam memahami permasalahan, peserta didik masih butuh arahan yang banyak dari pendidik.

Saat persentasi, peserta didik masih malu-malu tetapi peserta didik, namun peserta didik lainnya yang merespon lebih banyak dari pertemuan pada one to one. Dari segi waktu juga masih kurang dari yang direncanakan pada RPP tetapi jika dibandingkan dengan pertemuan 
sebelumnya, waktu yang digunakan sudah berkurang. Nilai yang diperoleh peserta didik dalam menyelesaikan soal yang berkaitan dengan pemecahan masalah sebagai berikut.

Tabel 6. Persentase Nilai Kemampuan Pemecahan Masalah Tahap Small Group

\begin{tabular}{|c|c|c|c|c|c|c|c|c|c|c|c|c|c|}
\hline \multirow[t]{2}{*}{ No } & \multirow{2}{*}{$\begin{array}{c}\text { Indikator Pemecahan } \\
\text { Masalah }\end{array}$} & \multicolumn{12}{|c|}{ Skor } \\
\hline & & \multicolumn{4}{|c|}{$\overline{P D 1}$} & \multicolumn{4}{|c|}{ PD2 } & \multicolumn{4}{|c|}{ PD3 } \\
\hline 1 & Memahami Masalah & 2 & 2 & 2 & 2 & 2 & 2 & 2 & 2 & 2 & 2 & 2 & 2 \\
\hline 2 & Merencanakan Penyelesaian & 3 & 3 & 3 & 3 & 2 & 3 & 2 & 3 & 2 & 2 & 2 & 2 \\
\hline 3 & Menyelesaikan Masalah & 2 & 2 & 2 & 2 & 2 & 2 & 2 & 2 & 2 & 2 & 2 & 2 \\
\hline 4 & Memeriksa Kembali & 1 & 1 & 1 & 1 & 1 & 1 & 1 & 1 & 1 & 1 & 1 & 1 \\
\hline & Total & 8 & 8 & 8 & 8 & 7 & 8 & 7 & 8 & 7 & 7 & 7 & 7 \\
\hline & Persentase & & $2, '$ & & & & 8,1 & & & & 3,6 & & \\
\hline
\end{tabular}

Berdasarkan tabel 6, terlihat bahwa pada indikator memahami masalah peserta didik dapat melakukan dengan baik dan dapat dilihat peserta didik mendapat rata-rata poin 2. Pada indicator merencanakan penyelesaian peserta didik kemampuan tinggi sudah mampu mencapai skor 3 begitu juga peserta didik kemampuan sedang. Pada indikator merencanakan penyelesaian peserta didik dengan kemampuan tinggi, sedang dan rendah dapat menuliskan semua langkah pengerjaan dengan tepat dan peserta didik rata-rata mendapat poin 2.

Pada indikator menyelesaikan masalah peserta didik dengan kemampuan tinggi pada soal pertama kurang lengkap dalam membuat perhitungan soal sedangkan pada soal kedua peserta didik dengan kemampuan tinggi dapat mengerjakan dengan baik. Peserta didik dengan kemampuan sedang dan rendah mendapat rata-rata poin 2 yang artinya peserta didik tidak lengkap dalam menyelesaikan perhitungan sesuai dengan langkah-langkah penyelesaian. Pada indikator memeriksa kembali peserta didik hanya menuliskan jawaban yang diperoleh dari hasil perhitungan tanpa dilakukan pengecekan apakah sudah benar atau belum. Rata-rata peserta didik mendapat poin 1.

Berdasarkan kedua kegiatan tersebut terlihat bahwa tingkat perkembangan nilai kemampuan pemecahan masalah peserta didik pada tahap one to one tidak selalu meningkat. Peserta didik dengan kemampuan tinggi terlihat ada peningkatan, sedangkan peserta didik kemampuan sedang dan rendah tidak menunjukkan adanya perubahan kemampuan.

Data kepraktisan desain pembelajaran berbasis RME diperoleh dari angket respon pendidik, angket respon peserta didik terhadap LKPD yang digunakan, lembar keterlaksanaan RPP. Angket respon pendidik ini bertujuan untuk mengetahui kepraktisan perangkat pembelajaran RME berupa LKPD yang telah dikembangkan. Angket ini diisi oleh pendidik setelah menggunakan perangkat pembelajaran tersebut. Secara keseluruhan hasil angket respon pendidik dapat dilihat pada tabel 7 .

Tabel 7. Hasil Angket Respon Pendidik

\begin{tabular}{llcc}
\hline No & \multicolumn{1}{c}{ Aspek yang Dinilai } & Nilai Kepraktisan & Kategori \\
\hline $\mathbf{1}$ & Daya Tarik & $87,5 \%$ & Sangat Praktis \\
$\mathbf{2}$ & Proses dan Kemudahan Penggunaan & $96,42 \%$ & Sangat Praktis \\
$\mathbf{3}$ & Waktu & $87.5 \%$ & Sangat Praktis \\
\hline & Rata-rata Kepraktisan & $\mathbf{9 0 , 4 7 \%}$ & Sangat Praktis \\
\hline
\end{tabular}

Berdasarkan hasil analisis angket respon pendidik terhadap perangkat pembelajaran diperoleh bahwa persentase aspek daya tarik $87,5 \%$, aspek proses dan kemudahan penggunaan $96,42 \%$, dan aspek alokasi waktu 90,47\% sehingga rata-rata kepraktisannya 90,47\% dengan 
kategori sangat praktis. Hal ini dapat disimpulkan bahwa desain pembelajaran berbasis RME yang telah dikembangkan praktis untuk digunakan dalam proses pembelajaran.

Angket respon peserta didik diisi setelah peserta didik melaksanakan pembelajaran menggunakan LKPD berbasis RME. Angket ini diisi bertujuan untuk mengetahui kepraktisan perangkat pembelajran berbasis RME yang telah digunakan. Secara keseluruhan hasil angket respon peserta didik dapat dilihat pada tabel 8.

Tabel 8. Hasil Angket Respon Peserta Didik

\begin{tabular}{cccc}
\hline No & Aspek yang Dinilai & Nilai Kepraktisan & Kategori \\
\hline $\mathbf{1}$ & Isi dan Penyajian & $87,29 \%$ & Sangat Praktis \\
$\mathbf{2}$ & Kebahasaan & $94,37 \%$ & Sangat Praktis \\
$\mathbf{3}$ & Kegraikan dan tampilan & $89,37 \%$ & Sangat Praktis \\
\hline & Rata-rata Kepraktisan & $\mathbf{9 0 , 3 4} \%$ & Sangat Praktis \\
\hline
\end{tabular}

Berdasarkan hasil analisis angket respon peserta didik terhadap desain pembelajaran diperoleh bahwa persentase aspek isi dan penyajian $87,29 \%$ aspek kebahasaan $83,98 \%$, aspek kegraikan dan tampilan 89,37\% sehingga rata-rata kepraktisannya $\mathbf{9 0 , 3 4 \%}$ dengan kategori sangat praktis. Hal ini dapat disimpulkan bahwa desain pembelajaran berbasis RME yang telah dikembangkan praktis untuk digunakan dalam proses pembelajaran.

\section{Kesimpulan}

Hasil penelitian menunjukkan bahwa desain pembelajaran matematika berbasis pendekatan Realistic Mathematics Education secara daring yang dikembangkan sudah memenuhi kriteria valid dan praktis dengan karakteristik, (1) desain pembelajaran jelas dari segi petunjuk penggunaan, bahasa, dan prinsip-prinsip pendekatan Realistic Mathematics Education, (2) desain pembelajaran mudah digunakan dalam kegiatan pembelajaran, (3) waktu yang disediakan untuk melakukan tugas-tugas dalam desain pembelajaran memadai.

\section{Daftar Pustaka}

[1] Bayu, E. P. S. (2017). Perancangan Perangkat Pembelajaran Mata Pelajaran Matematika Paket C Setara SMA. Inovasi Pendidikan, 2(18).

[2] Hardika dan Sutaryat Trisnamansyah: 2010. Model Pembelajaran Fasilitatif Untuk Peningkatan Kreativitas Belajar Program Pendidikan Kesetaraan Paket C .Jurnal Ilmiah VISI PTK-PNF - Vol. 5, No.2, Desember 2010

[3] Lely, Eka. 2019. Pelaksanaan Worshop Analisis Standar Isi Kurikulum 2013 Pendidikan Kesetaraan di Kota Bukittinggi. Hibah Kemenag (Tidak Publikasi)

[4] Mustofa Kamil, (2011), Pendidikan Non Formal, Bandung: Alfabeta.

[5] Nasution, M. N. (2015). Manajemen Mutu Terpadu. Bogor Ghalia Indonesia

[6] Ploomp, T, and Nieveen N. 2013. Education Design Research. Netherland: Kluwer Academic Decelopment (SLO).

[7] Purwananti, Yepi S. 2016. Peningkatan Kualitas Pendidikan Sebagai Pencetak Sumber Daya Manusia Handal. Proceeding International Seminar FoE Vol 1 Mei 2016. 
[8] Pramuditya, Surya, dkk. 2018. Desain Game Edukasi berbasis android Pada Materi Logika Matematika. JNPM (Jurnal Nasional Pendidikan Matematika) Vol. 2, No. 2, Hal. 165-179 p-ISSN 2549-8495, e-ISSN 2549-4937

[9] Pribadi, Benny. (2009). Model Desain Sistem Pembelajaran.Jakarta:Dian Rakyat

[10] Sadikin, Hamidah. 2020. Pembelajaran Daring di Tengah Covid-19). Jurnal BIODIK Volume 6 Nomor 02 tahun 2020.

[11] Syaiful Hamzah Nasution. Jurnal Kajian Pembelajaran Matematika Vol. 2 No. 1. Pentingnya Literasi Teknologi Bagi Mahapeserta didik Calon Pendidik Matematika: Universitas Negeri Malang. 2018 